\title{
21st Century competencies in Technical and Vocational Education and Training: Rhetoric and reality in the wake of a pandemic
}

\section{Joy Papier}

Institute for Post-School Studies, University of the Western Cape, Cape Town, South Africa jpapier@uwc.ac.za

https://orcid.org/ 0000-0003-2079-9430

(Received: 25 June 2021; accepted: 13 October 2021)

\section{Abstract}

There is general agreement about the need for vocational education and training to embrace so-called modern technologies in gearing up to deliver to young people a broad range of what have become known as 21 st century competencies, of which digital literacy, self-directed learning, and adaptive learning are but three. Recent Technical and Vocational Education and Training (TVET) policies in South Africa incorporate the language of future competencies that ought to be acquired by college students through their curricula and delivered by lecturers with appropriate professional training. But in April 2020, confronted by the global COVID-19 pandemic and an immediate hard lockdown, TVET colleges went into crisis mode to try to meet a government demand that no student be left behind. While blended and remote methodologies had been employed to some extent in a few college programmes, the pandemic suddenly launched all lecturers into technology dependent teaching and learning. This article is based on a survey of conveniently selected public TVET college lecturers early in the lockdown who were under enormous pressure to continue the academic programme remotely. The snapshot I obtained was one of anxiety and consternation, but also of deep concern for students and their wellbeing under inordinately difficult conditions. Their conflicting priorities while they tried to balance remote teaching responsibilities and personal needs were illustrative of Maslow's well-known theorisation of humans and their hierarchy of needs. The limited research I conducted for this article was exploratory at a time in the pandemic when there were more questions than answers in every sphere of social interaction. My findings, therefore, do not seek to be definitive and there was full understanding that the education and training landscape was dynamic and shifting. However, what can be shared here is a moment in time to appreciate the experiences of a critical component of the TVET college sector under emergency conditions, and the distance they would have had to traverse towards official exhortations to leave no student behind.

Keywords: future competencies, Technical and Vocational Education and Training (TVET), curricula, remote learning, blended learning 


\section{Introduction}

The South African government reacted quickly to the initial Coronavirus infections and went into a hard lockdown on March 26, 2020. With very short notice students had to leave residences, classes were suspended, and campuses became no-go zones. Technical and Vocational Education and Training (TVET) colleges moved from full contact face-to-face programmes to remote learning within a matter of days. To understand the extent of the shift it may be helpful to consider the nature of teaching and learning in TVET classrooms preCOVID-19, and how official policies prior to 2020 anticipated the direction in which vocational education ought to go, and the reasoning for this.

I begin this paper $^{1}$ with a general characterisation of vocational teaching and learning that policies on curricula and pedagogy sought to address prior to the pandemic, and global indications of the competencies required by 21 st century vocational graduates depicted in a few international studies. Thereafter I set out the results of a survey conducted among a convenient sample of TVET college lecturers (vocational educators or teachers in other contexts). Survey responses indicate the extent of the leap into technology-based teaching that lecturers were required to make with minimal preparation, and their responses to management expectations that no student be left behind. Their interaction with students revealed that the latter were also not ready to acquire high-level skills through modern technologies. After a brief summary of themes from the data, I situate the main findings within a review of emergent literature relating to educator readiness for technology infused pedagogies during the COVID-19 pandemic. The comparative literature shows many convergences in educator experiences of teaching and learning in the different contexts across which COVID-19 cut.

\section{Policy aspirations for TVET teachers and learners}

TVET policies in the last two decades have focused on quality improvement of vocational education so as to enhance the esteem, employability, and portability of college qualifications according to the White Paper on Post-School Education and Training (Department of Higher Education and Training, 2013). But pass rates since the introduction of the new college curriculum, the National Certificate (Vocational), in 2007 have improved only very slowly, with high numbers of students not completing their three-year qualifications, or not sitting their examinations, according to the Annual Performance Statistics issued in 2019 by the Department of Higher Education and Training (DHET). While the DHET sets yearly performance targets, mostly these are not met, and students continue to perform poorly in critical subjects such as mathematics and engineering science. Meanwhile, the expectations of the vocational sector have been increasing, with mounting pressure being exerted on it to absorb vast numbers of out-of-school youth who require learning pathways, as well as school

This paper is based on a webinar presentation I delivered in October 2020 during a series entitled Re-imagining TVET: The implications of Covid-19, organised by Nelson Mandela University. 
students who need second chance opportunities (Human Resources Development Council of South Africa (HRDC), 2019).

The reasons for poor performance in colleges are multi-faceted, as indicated by a few studies that have been conducted on TVET student achievement (Jeffery, 2015; Papier, 2009). Research recommendations made in these studies include the provision of excellent learning materials, more practical training, learning support and so on, but professionally trained educators are seen as key to improved student performance. DHET has recognised this in its legislation of a suite of new qualifications in the Policy on Professional Qualifications for Lecturers in TVET (2012), intended to professionalise vocational teaching and enable lecturers to acquire pedagogies appropriate to preparing vocational students for workplace environments in a changing world as described below. The new vocational teacher qualifications, gazetted some eight years ago, are slowly being rolled out by a few universities that are engaging in initial and/or ongoing professional college lecturer development.

It is against a background of substantive existing challenges that TVET colleges were thrust into a new reality in which the competencies projected as part of their changing world were suddenly upon them.

\section{TVET competencies for a changing world}

It is acknowledged the world over that a "new technology revolution is fundamentally changing our lives" (Schwab, 2016, p. 1). In a major edited reference work on trends and issues in vocational education and training around the world (McGrath et al., 2019), two extensive volumes convey clearly that the world of work is changing, and that wherever TVET is located it will have to contend with preparing students for a new reality that includes automation, digitisation, artificial intelligence, climate change, greening, and the like. We now know that the future in the aftermath of COVID-19 is even more uncertain and complex than initially envisaged (Organisation for Economic Cooperation and Development (OECD), 2018).

Education, along with training, is being called upon to address explicitly the competencies that young people need to survive and succeed in a 21 st century context; these are seen, generally, as skills that are relevant across many fields including subject knowledge and particular skills such as the ability to cope with complex problems and unpredictable situations (see Ehlers, 2020, and the edited collection of Pellegrino and Hilton, 2012). Finegold and Notabartolo (2010, p. 1) offered a useful revised grouping of 21st century competencies that depict the broad categories of skills as "analytic skills, interpersonal skills, ability to execute, information processing, and capacity for change." The discussion of these groups of skills shows clearly that digital literacy, problem solving, socially interactive skills and so on needed for working collaboratively and ethically, are just a few of the 21 st century skills the acquisition of which is becoming urgent. Several international iterations of the desired competencies have emerged recently. The OECD's Future of education and skills, 
2030 is a future-focused document intended to provide an "evolving learning framework that sets out an aspirational vision for the future of education" (OECD, 2019a, p. 1). Harvard University's Center for Curriculum Redesign (Fadel et al., 2015) has its own education framework that is comprised of the four dimensions of knowledge (what we know and understand); skills (how we use knowledge, what we do with what we know); character (how we behave and engage in the world); and meta-learning (how we reflect and adapt). These competencies are intended to be cultivated deliberately through pedagogies that support deeper, meaningful learning, not at the expense of teaching strong disciplinary content, but for the purpose of being able to discern when, how, and why disciplinary knowledge is applied.

Lecturers would themselves have to possess the appropriate skills and pedagogies to assist students successfully in their acquisition of the abovementioned competencies. Furthermore, college infrastructure would have to be upgraded to enable enhanced online and technological delivery as part of new learning modalities. An Education, Training and Development Practices (ETDP) sector authority report citing Czerniewicz and Carr (2014, p. 2) stated that

[t]he colleges' IT infrastructure is one clear area that requires attention if open learning platforms are to be used. This will require not only investment in hardware and learning management software, but also training for the IT staff and the lecturers to make effective use of these methodologies . . . access to WIFI on all college campuses will need to be expanded, with simultaneous ongoing training of lecturers. (ETDP SETA Report, 2019/20, p. 18)

However, some strides are being made in, for instance, extending college broadband infrastructure (see South African Broadband Education Network (SABEN), 2021), improving open online learning resources (see DHET Open Learning for Post-School Education and Training (PSET)), and training programmes for college lecturers, but these initiatives are still in process and rollout has been uneven in the different colleges around the country. In addition, recent TVET college government interventions such as the Centres of Specialisation $(\mathrm{CoS})$ project (modernised programmes that combine institutional and workplace learning in priority trades) had already acknowledged the necessity for new teaching and learning technologies in TVET by the time COVID-19 struck. The sudden advent of the pandemic, however, revealed the chasm between future-focused planning and a delivery for which TVET lecturers were largely unprepared since the pandemic thrust most of the college sector into hastily conceived contingency plans to support learners and sustain learning under very difficult conditions.

\section{The impact of COVID-19 on an already stressed college environment}

By all accounts, South African TVET college students have struggled in class, even with a teacher physically present, as pass rates over the last decade have revealed (DHET, 2019). TVET college statistics show that the fiscus funded National Certificates (Vocational) 
(NC(V)) exit Level 4 had a pass rate of about only 49 percent in 2019 (albeit that pass rates have been improving slowly since). More worrying though, is that across the lower levels of the NC(V) and Report 191/National Accredited Technical Education Diploma (NATED) programmes there is annually a significant drop-off in student numbers evidenced by those enrolled compared with those who sit the examinations in all courses. So, my question is, "How would these students fare with a teacher at a distance, having to rely on resource-based learning, and with less classroom interaction through group learning or practical activities/simulations no matter how inadequate the latter?"

Given the poor general schooling foundations that many TVET college students have experienced prior to attending college, lecturers perform an essential task in mediating learning content and more particularly in relation to introducing unfamiliar or new concepts. Lecturers in various workshops I have conducted have reported how important it is to see understanding dawn on the faces of their students, and how they have revelled in the aha moments, and in being able to read students' body language that expresses how the learning is being received. These aspects of teaching, so discernible in a classroom situation, did not seem possible when lecturers were many miles away from their students, and when video receptive devices were not readily available, as the evidence I offer later reveals.

In the absence of face-to-face contact for mediating essential content with students, lecturers would thus have had to rely on communication and learning affordances that come as close as possible to the physical teaching and learning situation. But here the so-called digital divide was obvious. Mpungose (2020), in his study of university students during the pandemic referred to the digital divide as "the gap between those who have and do not have access to computers and the Internet" (p. 2), and that hampers the South African move to e-learning in higher education in spite of efforts to provide data and devices to students. His findings showed that the university did not have an e-learning policy in place, and neither was adequate training provided. Furthermore, he averred that "many students did not have laptops in spite of the university having provided these, and they preferred their mobile phones with free network data bandwidth for communicating amongst themselves" (p. 7).

The difficulties of continuing learning under lockdown and the dilemma faced by TVET lecturers surveyed (and the students) are aptly described as representing a case of "Maslow before Bloom" (Berger (2020) cited in Jeffrey 2020, para. 8); see also Porter, 2020.) In his well-known theorisation Maslow's hierarchy of needs or human motivations at seven levels - the physiological, safety, belongingness, love, esteem, self-actualization and selftranscendence-describes the transitions or growth that human beings experience in life. At the most basic level humans have to satisfy their bodily needs of food, shelter, and safety before they can move on to focusing on emotional needs, and only then can they consider higher level self-actualisation desires. Bloom's taxonomy, however, with its range of cognitive development across the six levels of knowledge, comprehension, application, analysis, synthesis, and evaluation, refers to stages in the cognitive domain in his theorising of how the brain processes information. By somewhat facetiously juxtaposing Maslow and Bloom, the point being made is that human beings need to have their basic physical needs 
met before they can be concerned with progressing through cognitive levels. The Maslow vs Bloom prism was particularly helpful to me in appraising the experiences of college lecturers at the onset of the COVID-19 crisis that resulted in an almost immediate lockdown. It was apparent from the survey responses that while the hiatus in teaching and learning was deeply concerning, it was overshadowed by concerns for personal health and safety, and the conditions under which students and lecturers had to function.

\section{Taking the temperature: TVET lecturer responses to remote teaching and learning}

Early in the South African lockdown in May 2020, I conducted a small, targeted survey of college lecturers located in three provinces, the Western Cape, Eastern Cape, and Gauteng. The respondents consisted largely of full-time college lecturers who were also postgraduate candidates enrolled in the institution in which I was based, so they provided a convenient sample, especially since they were teaching in colleges across more than one province. The group of thirty college lecturers presented an opportunity for me to learn first-hand how they were experiencing the impact of COVID-19 at their colleges early in the pandemic. In this snapshot survey research of limited scope, I was essentially testing the water at a particular point in time when, as a country, people everywhere were at their most vulnerable and most uncertain about the future. I undertook this survey in response to anecdotal reports that college lecturers were struggling to maintain their academic responsibilities, so I intended to gather some empirical data at a time of deep crisis - a situation that always appears easier with hindsight.

The sample was by no means representative, but the methodology enabled me to identify respondents across 10 (of 50) public colleges i.e., 6 in the Western Cape, 2 in the Eastern Cape, and 2 in Gauteng, and to gain consent for their participation. Since colleges were about four weeks into the lockdown, it was an opportune moment to find out how they were experiencing the sudden shift and obtain voluntary input from those willing to share their thoughts and feelings on the new modality they were being asked to adopt early in the COVID-19 crisis.

I decided to pose open-ended questions given the small scale of the survey, and to enable me to elicit authentic, unrestricted, and candid responses. The questions probed lecturers' views on how their students were coping with remote teaching and learning under conditions of lockdown and on how their colleagues were coping, their impressions of college planning, and their associated feelings/fears/anxieties at the time. I coded the 30 completed questionnaires analytically in line with an interpretive approach, and in terms of the categories of responses obtained for the particular questions I asked. I then undertook a qualitative content analysis in terms of the codes identified and this yielded the themes I report on below. Since the intention with this research was to obtain the perspectives of college lecturers, the emphasis was on allowing the data to speak for itself as far as possible. For purposes of this paper of limited scope, I provide only a selection of extracts from the 
data (anonymised attributions by means of assigned data codes in order to protect confidentiality) for illustrative purposes.

\section{Summary of themes extracted from the data}

The responses from lecturers at the height of the Covid-19 crisis in education and training reflect sharply the realities of government's call to leave no student behind and to save the academic year. The themes I report on below summarise for purposes of this article the main concerns voiced by college lecturers, and then, in the section that follows, I situate them within the broader debates emerging in the literature at the time of the research in 2020.

\section{Unconducive conditions for remote teaching and learning}

It was evident from the lecturer feedback in the study that students struggled to continue their learning at home. At a basic level many homes were not conducive to study nor to distance education. Connectivity and other affordances were not readily available, some families had lost incomes because of their being unemployed during lockdown, and bereavement following deaths from COVID-19 was affecting students. The majority (90\%) of lecturer comments were negative about the abilities of students (and staff) to work from home, albeit for slightly different reasons.

Many (students) are in informal settlements. Above all, most learners indicated that they cannot study at home because of overcrowding conditions coupled with high noise levels and it is difficult to have study times within their homes. Some students send messages indicating that they cannot learn online and prefer face to face. (Lecturer A1)

They might be able to, but they won't for personal reasons and domestic reasons, as the living conditions are mostly not conducive to learning. Some learners are unreachable. Some have changed cell phone numbers or may have lost the cell phone. (Lecturer A4)

One of the biggest issues is that staff and students do not have the resources required to work from home. Data costs in South Africa [are] ridiculously expensive and the majority of our students come from very poor backgrounds. Most of the students at our colleges live from hand to mouth and their purpose for studying is to improve basic living conditions. Where the majority of our students come from, the areas are worst affected. (Lecturer G2)

Two thirds of lecturers reported they could themselves identify with the difficulties experienced by their students since conditions in their own homes were not conducive to teaching remotely. Some had extended family living with them, and their accommodation was too small for them to devote a quiet space to teaching and engaging with their students. Women staff members, in particular, seemed to bear the brunt of working from home since they had to tend to their children when schools or day-care centres were closed, and homeschooling them was time consuming. 
In a report on a workshop held at Stellenbosch University, Bugan (2020) referred to a keynote address by eminent education scholar Jonathan Jansen with regard to a study entitled "Gender inequality in the shadow of COVID-19" for which Jansen and colleagues conducted research among a sample of women academics at South African universities. In this study the impact of the pandemic on women academics in particular was striking in that women continued to work in spite of having to carry out regular household chores and take care of children in a congested space in which many were competing for broadband. Women academics' productivity was negatively impacted by institutional pressures and their feelings of responsibility to nurture anxious students. There was considerable guilt in balancing work and home lives, but it was remarkable, respondents felt, that, "despite the pandemic, the demand for academic performance from university management continues as if nothing has happened" (Bugan, 2020, n.p.).

Similar feelings of frustration were echoed by TVET college lecturers who felt that college authorities were not being sympathetic to their plight, as the extracts below illustrate. The first extract is illustrative of the majority of lecturers (80\%) fearful for their health and safety, while the second reflects more pragmatic views (20\%) of the understanding that COVID-19 might be around for a long time and there was, therefore, a need to adapt to its continued presence and make the best of a difficult situation.

Although most of the TVET college sector was not prepared, we have done our best in this situation. Perhaps it would be better to freeze the academic year for just one year, or simply take up lost time in the overlap of each year, until we accommodate the time lost due to the pandemic. We should rather focus on the safety and emotional and psychological well-being of the staff. The reality of each college \& institution is so different especially with regard to available resources. (Lecturer G5)

I somehow feel that TVET authorities want to place curriculum ahead of safety. However, it is reality that we will have to get back to work because of the economic situation in the country. Thus, we will have to learn to live with Covid in our midst . . . using personal vigilance and hygiene. (Lecturer G6)

\section{Inability to learn remotely and independently}

In responding to whether students would be able to learn using online and remote teaching methods, most (90\%) of the lecturers surveyed were emphatic that TVET college students in their courses would not be able to navigate online content without substantive lecturer guidance, especially in the $\mathrm{NC}(\mathrm{V})$ programmes in which students were thought to be "too immature to take responsibility for their own learning" (Lecturer A9). Lecturer A8 (see below) felt that students might be able to learn on their own under certain conditions. A number of students had sent their lecturer messages to say they could not learn online and preferred to be able to "hear the teacher, and to ask questions" (Lecturer A23). Some extracts from the data further illustrate this sentiment. 
No, most of the students will not be able to cope on their own ... students have already indicated that self-study is a challenge for them . . . to learn on their own and break down concepts. I think it is even more challenging when the course they are studying has a large practical component to it. (Lecturer A5)

The students in this context will not be able to cope in a platform that requires autonomous learning methods. Especially since their lecturer was always present in face-to-face learning sessions. Learning independently from textbooks and online learning results in many challenges. Students struggle to read and interpret information on their own. (Lecturer A3)

To a certain extent they can learn independently from textbooks and online, however, only really within a well-conceived blended context. Our TVET learners generally do not have the cognitive maturity to handle online learning completely on their own (this is not meant as derogatory) and rely on guided learning. (Lecturer A8)

NATED students can cope when studying independently because they are more mature, but NCV students may suffer because they mostly. . . want to be policed to do and complete their work. (Lecturer A7)

\section{Lack of learning affordances}

With regard to affordances for remote learning, $40 \%$ of respondents mentioned their colleges' use of the free Moodle platform for engaging with learners and for posting learning materials, but high data costs at the time proved prohibitive. WhatsApp was the predominant means for keeping in contact with students for over $70 \%$ of lecturer respondents, but, according to them, the platform did not lend itself to volumes of information, and the small phone screen was difficult to manage. Often, there were no responses from "students who simply kept under the radar" (Lecturer A25). Students appeared to have access mostly to cell phones for downloading content rather than computers. But the problem reported in relation to unanswered WhatsApp messages was that many students live in areas in neighbourhoods where cell phone theft is rife, and phones were often stolen. In addition, students struggled with data or wi-fi capability, as these extracts explain.

Because of the lack of access to computers the learning takes place on phones. However, adequate data remains a challenge. (Lecturer A2)

I have received numerous complaints that my students do not have data to go online, besides some of them asked if the college could buy them cell phones as well . . cell phones are often stolen leaving them stranded. (Lecturer A1)

Online content is the most challenging due to the fact of it requiring internet access. Internet access is highly limited as students cannot afford data, and some not owning devices that can access the internet. Conclusively, students are not coping well without the face-to-face mediation of the lecturer, based on correspondence with students in the WhatsApp platform. (Lecturer A3) 
Most (60\%) of the sampled college lecturers also reported that they had relied on college computer and printing facilities for doing their lesson preparation, and they, and their colleagues, had varying levels of access to affordances like data and devices for working from home, nor could they afford the resources needed to do so.

Although not all lecturers are in the possession of a college laptop, they willingly use their personal resources due to the intensity of the challenges faced during the lockdown. The main things needed are compatible mobile devices, laptops, internet access, and most importantly, high efforts and dedication. Not one lecturer was prepared or trained for such emergency education situations. (Lecturer B5)

... most lecturers have a lack of connectivity hampering their efforts because data is expensive. The college should provide data to the lecturers. Although some lecturers are able to use online learning tools, they need re-training or refresher course. It is a catch-22 situation, because the college did not have prior budgets for this unexpected expense. (Lecturer B1)

Deep-seated fears and anxieties: Fear of infection and anxiety about the academic year

The early days of the pandemic resulted in widespread fear and anxiety as the following extracts, illustrative of $80 \%$ of the sample, indicate. Fear of infection was heightened among lecturers at the time, with responses relating to the safety of self and their immediate family members predominant, but also to fears for students' safety.

Some lecturers and students commute using taxis, and it is worrisome because their health /safety will be undermined if the College and government do not put enough mechanisms to manage this. In addition, lecturers are sceptical about the level of preparedness to re-open particularly in terms of provision of sanitary measures. (Lecturer C1)

As an asthmatic, I am fearful of contracting Covid-19 as I fall in the high-risk category. There are many staff members who are over 60 and with underlying medical conditions that put them at risk. My concern is that TVET leadership is currently not taking the matter seriously and have not come up with a plan of how to deal with this. (Lecturer C8)

Anxieties were also related to how students were coping with the workload without physical access to their teachers, to the accessibility of content for students, and to how exams would be conducted. Lecturers were not convinced of their students' preparedness for examinations.

We are anxious because we are not able to reach $100 \%$ of learners. This could be because not all learners have access to electronic devices or data. However, in some instances learners have never been exposed to online platforms and are insecure. Some learners are not motivated enough to go the extra mile to ensure that they succeed and do not take ownership of their studies. (Lecturer C3) 
Our main anxieties lie with the accessibility of the content for students. Not all students have internet access for obtaining online content, making it extremely difficult for learning to take place. Readily available data is scarce due to the cost for the students. In addition, some students do not own mobile devices compatible with using WhatsApp. (Lecturer C4)

Some are concerned with how the academic year will be saved, especially with regard to the exit level students. Lecturers are anxious about the workload with unrealistic deadlines. The way in which examinations will be conducted is also a great concern. (Lecturer C6)

The 2020 performance statistics will be an important indicator of the impact of the COVID19 year on student academic performance, but this will likely be available only in 2022 since departmental statistics reports are produced two years retrospectively. Nonetheless, it will be a moment to reflect soberly on what had been demanded from students and lecturers, and the gap that had to be breached in order to meet official expectations.

Many lecturers felt anxious about their abilities to use computer technology properly, expressing that they felt generally inadequately prepared for what the college was expecting of them.

The anxiety stems from the move from traditional to online learning where many feel challenged by technology and its use in online learning. (Lecturer C7)

I so wish that our TVET sector can be realistic in terms of their expectations. We are all doing our best to flatten the curve, but we still remain scared of the virus. Returning to work is never going to be an easy exercise especially for people with underlying illnesses as disclosing your health status is never an easy task. (Lecturer G3)

\section{A general mood of uncertainty}

When asked to describe their mood and that of their colleagues, lecturers used descriptors that were simple yet eloquent. A word graphic revealed these commonly used adjectives, from highest to lowest frequency: anxious, overwhelmed, unprepared, daunted (by technology), lost, confused, scared, frustrated, and rushed.

About half of the respondents chose to offer more explanatory responses.

We are scared and frustrated because we are struggling under normal circumstance so we have no idea what the consequences of these uncertain times will be in terms of our learners' academic performance (that is my greatest fear). (Lecturer F9)

Generally, the mood is 'cautious' and 'pensive' about Covid and the workplace. However, the majority are keen to get back to a sense of normality. Staff are looking 
for a good plan from management that assures their safety and enables students to engage in meaningful T\&L. (Lecturer F11)

\section{Summary of lecturers' concerns}

What was striking from the survey data was that lecturers across the three South African provinces, from a range of TVET colleges, clearly demonstrated the Maslow/Bloom dilemma they experienced with regard to their responsibility for teaching and learning on the one hand, and how they were being affected physically and emotionally by the pandemic on the other. The following issues could be distilled from the majority of the respondents' feedback.

- Lecturers were conflicted by fears for their health and safety should the college try to return to face-to-face learning prematurely;

- Lecturers were frustrated by what they perceived to be the authorities' focus on continuing the learning programme at the cost of compromising staff health;

- Lecturers were deeply concerned about losing contact with their students due to the lack of affordances for communicating and teaching;

- Lecturers were anxious about their own access to necessary devices and connectivity and the personal cost thereof; and

- Lecturers were worried about students not being able to learn without face-to-face contact classes, and possibly losing them through failure or drop-out.

The concerns set out above found purchase in the comparative literature, most of which emanated around the time that the local survey on which I am reporting here was conducted, but came also from countries that had been exposed to the Coronavirus before it reached South African shores so these writers had more time during which to assess its impact. This short review does not purport to take in all of the extant literature, but it serves to locate the local study within a broader research context.

\section{Comparative experiences of the impact of COVID-19 on teaching and learning}

It can be seen from the brief round-up of international research that was being done relatively early in the pandemic, that vocational education the world over, even in more established systems, was undergoing experiences similar to those expressed by educators in my local study. The concerns distilled from this local survey were remarkably similar to those reported below.

Hoftijzer et al., in a World Bank blog (2020, para. 2), echoed the sentiments expressed by college lecturers in South Africa at the height of the pandemic.

The degree to which learning can still take place outside the classroom, including in TVET, is often limited by lack of access to electricity, internet connectivity, devices or media, learning platforms, or the inadequate preparation of instructors and students 
for remote education. Some students, particularly women and girls, face additional constraints in terms of time availability due to competing responsibilities, such as caring for children and elderly family members and other household duties.

Adjustments to distance learning can be the hardest in low-income contexts and among vulnerable students.

The blog continued to note that TVET learning that should have a focus on practical application and work preparation, may be hardest hit by remote learning, since "remote learning approaches are a weak substitute for practical exercises when they require the use of equipment or materials not usually found inside the home." (para. 3).

Another international publication (International Labour Organisation (ILO) Policy Brief, 2020a, p. 1) noted that "the shift to online or distance learning during the pandemic should be seen first and foremost as an emergency response." But it holds that COVID-19 definitely opened the door to more flexible learning solutions, albeit ones born of necessity and the acknowledgement that college managements, educators, and students need extensive training and support to engage fruitfully in remote and online learning.

Across the world in TVET colleges, for instance in Europe, Russia, Bangladesh, and Latin America, reports show the emergency measures that had to be taken to continue learning and teaching (ILO, 2020b; ILO Cinterfor, 2020). Video recordings, free online training platforms, Facebook, webinars, public radio channels, and other affordances are some of the examples of the explosion of interventions that resulted from the crisis in education delivery. COVID19 has clearly become a catalyst for educational institutions worldwide to search for innovative solutions in a relatively short period of time. Diverse stakeholders such as governments, publishers, education professionals, technology providers, and telecom network operators came together to use digital platforms as a temporary solution to the crisis.

However, the literature also reveals the huge regional inequities in digital infrastructure and capacity, more so in the TVET and skills sector where under-investment has limited the quality of both face-to-face and online delivery over the long term in many countries. A recent survey by the World Bank in Central Asia found that $70 \%$ of countries had minimal distance learning capabilities, with no country having universal online curriculum-linked resources for teaching and learning (World Bank, 2020). Even European education systems were found to be underprepared for digitalisation, with $40 \%$ of European Union citizens lacking basic digital skills and fewer than $40 \%$ of teachers and trainers receiving training on educational technologies during their initial teacher education (Solidar Foundation, 2020). Alongside the need for digital skills, attitudes and behaviours towards digital learning are also proving to be of major importance. Learners appeared to struggle with maintaining engagement in digital courses because of the lack of a supportive context, previous experience, and/or adequate instructional methods. The transition from face-to-face to distance and blended learning has clearly been daunting for both students and teachers.

With regard to educators, online learning prior to COVID-19 had been anticipated as a means to expand access to tertiary education, with a number of studies being conducted to examine 
its implications for teacher preparation, inter alia. In a study that investigated university teacher educators' readiness and attitudes towards a change to online learning in their preservice teacher programmes, Downing and Dyment (2013) found that, "the majority of teacher educators initially reported lacking confidence and competence with the technological and pedagogical skills required to teach online" (p.106 ). Budhrani et al. (2019, p. 98), with regard to lecturer preparation for online learning noted that "course design involves not only preparing materials, course lectures, activities, and assessments in advance, but also providing clear expectations of assignments and/or activities, and anticipating student questions."

Cutri et al., (2020) described the sudden transition to online learning by their university in the USA at the onset of the pandemic as "crisis online course transitioning." Few of the lecturers in their teacher education faculty had ever taught online or in blended formats before. With university closures, these staff members had to create and implement online teaching with minimal preparation, and with no choice. The authors concluded that "the conditions of transitioning to online classes during a crisis rendered a longitudinal perspective on readiness and expertise almost useless" (p. 524).

Brooks and Grajek (2020), summarised a series of reports on educator readiness for the sudden move to online learning during the pandemic in the US and commented that

there are huge gaps between the work faculty are being asked to do and the tools that are being provided to conduct that work. . . many faculty will be woefully unprepared or underprepared to take on the task of creating quality online learning experiences for their students." (para. 2)

Furthermore, they reported that

only $6 \%$ of faculty prefer to teach completely online courses ... The institutional support needed to transition faculty to completely online courses is monumental, and that burden could have cascading negative consequences for long-term instructor morale and disposition toward online courses generally. (para. 5)

In some institutions they averred that

teaching face-to-face has as much to do with teaching philosophy and instructional identity as it does with pedagogical approach ... One of the reasons faculty don't want to teach online is that they don't believe it helps students learn effectively. (para. 6)

Junus et al., (2021) pointed to the many aspects that must be taken into account in moving to e-learning in their noting that

transition to e-learning is the whole process of change, the actual conversion of each course in an institution, including the training of faculty, and the faculty finalizing their courses and then migrating to the new online environment . . . even in normal 
conditions, transition from face to face to e-learning is considerably time consuming and changes the faculty's role and teaching responsibilities. (p. 3)

The comparative experiences of the impact of COVID-19 on education and training around the world were largely consistent with that of South Africa at the onset of the pandemic. In particular, the emphasis on what was needed by learners and lecturers compelled prematurely into remote learning, in terms of resourcing, skills, and attitudes, found resonance in the local study I have described. In contrast with the reflective comparative studies, though, time needs to be taken in South Africa to focus on the innovations in TVET pedagogy and practices that have undoubtedly come to the fore since I did the research on which this article is based.

\section{Concluding comment}

In this article, I have attempted to offer some insight into the experiences and views of TVET college lecturers in South Africa at a moment of intense uncertainty, confronted as they were by an inexplicable global and national threat, and with no idea as to how the situation would unfold after March 2020 when government responded with serious measures to halt the spread of the Coronavirus.

Despite advances in blended and remote learning approaches at the time and interventions for developing digital literacy skills among TVET students in process, when the pandemic struck, TVET institutions were, for the most part, not ready, willing, or able at short notice to substitute face-to-face interactive pedagogies for technology-dependent remote learning and teaching. Evidence from around the globe tells a similar institutional story, but also demonstrates the importance of acknowledging systemic weaknesses and collaborating in seeking solutions that address the needs of the most vulnerable.

In all crisis situations there are inevitably gains and losses. The sudden advent of Covid-19 impelled adaptation and innovation and rendered lessons that need to be reflected in policies and practices in the aftermath of the immediate crisis. As the dust begins to settle for TVET colleges there has to be serious appraisal of the conditions under which learning has taken place, how successful or otherwise it has been (performance statistics for 2021/21 may be an indicator of this), the unintentional learning that did occur, and the physical and emotional toll it has taken on all role-players.

\section{Acknowledgement}

The author acknowledges the support of the South African National Research Foundation (NRF), through the South African Research Chairs Initiative (SARCHi) and specifically the TVET Teaching and Learning Chair, which supported her in the writing of this article. All views expressed, however, are the author's own and are not attributable to the NRF. 


\section{References}

Brooks, D. C., \& Grajek, S. (2020, March 12). Faculty readiness to begin fully remote teaching. EDUCAUSE Research Notes. [Blog].

https://er.educause.edu/blogs/2020/3/faculty-readiness-to-begin-fully-remote-teaching

Budhrani, M. F., \& Wang, C. (2019). Examining faculty perception of their readiness to teach online. Online Learning, 23(3), 97-119. https://doi.org/10.24059/olj.v23i3.1555

Bugan, D. (2020). New study probes Covid-19 impact on women academics. Report on a workshop in the EMS Faculty at Stellenbosch University. https://www.sun.ac.za/english/Lists/news/DispForm.aspx?ID=7711

Cutri, R. M., Mena, J., \& Whiting, E. F. (2020). Faculty readiness for online crisis teaching: Transitioning to online teaching during the COVID-19 pandemic. European Journal of Teacher Education, 43(4), 523-541. https://doi.org/10.1080/02619768.2020.1815702

Department of Higher Education and Training. (2012). Policy on professional qualifications for lecturers in Technical and Vocational Education and Training. Department of Higher Education and Training.

Department of Higher Education and Training. (2013). White Paper for Post-school Education and Training: Building an expanded, effective and integrated post-school system. Department of Higher Education and Training.

Department of Higher Education and Training. (2019). Annual Statistics on Post-School Education and Training. Department of Higher Education and Training.

Downing, J. J., \& Dyment, J. E. (2013). Teacher educators' readiness, preparation, and perceptions of preparing preservice teachers in a fully online environment: An exploratory study. The Teacher Educator, 48(2), 96-109.

Education and Training Development Practices Sector Education and Training Authority (ETDP SETA). (2019). TVET Sub-sector Report for the 2019-20 Sector Skills Plan. Department of Higher Education and Training.

Ehlers, U. (2020). Future Skills: The future of learning and higher education. Books on Demand.

Fadel, C., Bialik, M., \& Trilling, B. (2015). Four-dimensional education: The competencies learners need to succeed. Center for Curriculum Redesign. https://curriculumredesign.org/our-work/four-dimensional-21st-century-educationlearning-competencies-future-2030/ 
Finegold, D., \& Notabartolo, A. (2010). 21st-century competencies and their impact: An interdisciplinary literature review. Board on Training and Assessment. http://www7.nationalacademies.org/bota/Finegold_Notabartolo_Impact_Paper.pdf

Hoftijzer, M., Levin, V., Santos, I., \& Weber, M. (2020, May 4). TVET (Technical and Vocational Education and Training) in the times of COVID-19: Challenges and Opportunities. https://blogs.worldbank.org/education/tvet-technical-and-vocationaleducation-and-training-times-covid-19-challenges-and-opportunities

Human Resources Development Council of South Africa. (2014). TVET Colleges technical task team final report. HRDC.

International Labour Organization. (2020a). Policy Brief. Distance and online learning during the time of COVID-19. https://www.ilo.org/wcmsp5/groups/public/---ed_emp/--ifp_skills/documents/publication/wcms_743485.pdf

International Labour Organization. (2020b). Continuing online learning and skills development in the time of the COVID-19 crisis. https://www.ilo.org/wcmsp5/groups/public/---ed_emp/--ifp_skills/documents/publication/wcms_766557.pdf

International Labour Organization CINTERFOR. (2020). The role of Vocational Training against the effects of COVID-19 in Latin America. https://www.oitcinterfor.org/en/publications/ilocinterfornotes/vt_covid

Jeffery, D. G. S. (2015). Academic Support: How do students think about it? A study in a South African TVET College. [Unpublished Master's Thesis, Nelson Mandela University].

Jeffrey, S. (2020). Student wellbeing: Maslow before you bloom. The voice for secondary education (SECED). https://www.sec-ed.co.uk/best-practice/student-wellbeingmaslow-before-you-bloom-mental-health-covid-19-teaching-pedagogy/

Junus, K., Santoso, H. B., Putra, P. O. H., Gandhi, A., \& Siswantining, T. (2021). Lecturer readiness for online classes during the pandemic: A survey research. Educ.Sci., 11(3), 139. https://doi.org/ 10.3390/educsci11030139

McGrath, S., Mulder, M., Papier, J., \& Suart, R. (Eds). (2019). Handbook of Vocational Education and Training: Developments in the changing world of work. Springer.

Mpungose, C. B. (2020). Emergent transition from face-to-face to online learning in a South African university in the context of the Coronavirus pandemic. Humanities and Social Sciences Communications, 7(113), 1-9. https://doi.org/10.1057/s41599-020-00603-x 
Organisation for Economic Cooperation and Development (2018). Preparing humanity for change and artificial intelligence: Learning to learn as a safeguard against volatility, uncertainty, complexity and ambiguity. http://www.oecd.org/ education/2030/Preparing-humanity-for-change-and-artificial-intelligence.pdf

Organisation for Economic Cooperation and Development (2019a). Future of education and skills 2030. Conceptual learning framework. Concept note: Skills for 2030. http://www.oecd.org/education/2030-project/teaching-and-learning/learning/ skills/Skills_for_2030.pdf

Organisation for Economic Cooperation and Development (2019b). OECD Future of education and skills 2030. OECD Learning Compass 2030. A series of concept notes. http://www.oecd.org/education/2030-project/contact/OECD_ Learning_Compass_2030_Concept_Note_Series.pdf

Papier, J. (2009). Getting the right learners into the right programmes? An investigation into factors that contributed to the poor performance of FET college learners in NCV 2 and NCV 3 programmes in 2007 and 2008- Reasons and recommendations. Report prepared for the Western Cape Education Department (WCED). Further Education and Training (FET) Institute.

Pellegrino, J. W., \& Hilton, M. L. (Eds.). (2012). Education for life and work: Developing transferable knowledge and skills in the 21st century. The National Academies Press.

Porter, T. (2020). Reflecting on teacher wellbeing during the COVID-19 pandemic. REL Pacific. [Blog]. https://ies.ed.gov/ncee/edlabs/regions/pacific/blogs/blog28_reflectingon-teacher-wellbeing-during-COVID-19-pandemic.asp

South African Broadband Education Network (SABEN) Newsletter. (2021, April). https://www.saben.ac.za/about/saben-newsletters/

Schwab, K. (2016). The fourth industrial revolution. Crown Publishing Group.

Solidar Foundation (2020), Briefing note-E-learning: Universal access to education at a time of online learning. https://www.solidar.org/en/publications/briefing-note-e-learninguniversal-access-to-education-at-a-time-of-online-learning 